\title{
On the medical history of the doctrine of imagination $^{1}$
}

\author{
ESTHER FISCHER-HOMBERGER ${ }^{2}$
}

\section{From the Medizinhistorisches Institut der Universität Bern, Switzerland}

SYNOPSIS In the early modern era the notion of imagination was made responsible for phenomena which were later explained in terms of embryology, genetics, psychology, bacteriology or other scientific disciplines. Images, often seated in the upper abdomen (hypochondriac region) or the womb (hysteria), were regarded as powerful influences on material reality. In the course of the seventeenth and eighteenth centuries the hypochondriac forms of imagination became mere whims and spleens, but they kept much of their original potency in respect of the uterus, accounting for monstrosities and the shaping of human offspring. The hysterical conversion of imagination into somatic phenomena has never been questioned. Since the two World Wars the realm of imagination has again expanded beyond the uterus and the older disease-concepts. In the last 10-20 years images seem to have regained some of their original creative force.

\section{IMAGINATION, IDEA, CREATIVITY}

\section{The psychogenesis of phenomena during} the sixteenth and seventeenth centuries

According to Brockhaus' standard German dictionary (1960) imagination is equated with 'mental images to which no corresponding reality exists'. In a similar vein Webster's Dictionary (1958) refers to 'an act of forming mental images of what is not present'. Imagination has not always had such an aura of remoteness from reality. During the sixteenth and seventeenth centuries these images retained some reality and were almost respectfully called 'imaginatio'. Medicine too accepted their reality.

In 1586 a book entitled On the Mcdicine of Miracles was published in Mantua (Donatus, 1588). In the first chapter of its second part the author, Marcellus Donatus (d. ca. 1600), discusses in some detail the miraculous effects of imagination which, he maintains, influences the

\footnotetext{
1 This paper is a slightly enlarged version of "Aus der Medizingeschichte der Einbildungen' which is contained in: E. Fischer-Homberger (1979): Krankeit Frau und andere Arbeiten zur Medizingeschichte der Frau pp. 106-129, 150153. Huber Verlag: Bern-Stuttgart-Wien. (Pp. 160; illustrated; DM 38.) Translated from the German by E. H. Ackerknecht.

${ }_{2}$ Address for correspondence: Professor Esther FischerHomberger, Medizinhistorisches Institut der Universität Bern, Bühlstrasse 26, CH-3012, Bern, Switzerland.
}

body by means of such faculties as those concerned with digestion, excretion and reproduction. We yawn, for example, when we see others yawning, just as we vomit when we see something disgusting. A women may give birth to a very hirsute child because during pregnancy the mother had repeatedly looked at a picture of St John the Baptist, covered with fur. It was, according to Donatus, due to imagination that white hares, foxes, bears, raven, mice and peacocks are seen in snowy regions. A woman, impregnated at the time of Epiphany, had three sons, one as black as the black king. Another woman whose husband threatened to split her skull during pregnancy gave birth to a child with a fractured skull, which bled to death immediately after delivery. Another mother, who had seen a case of hydrocephalus, herself delivered a hydrocephalic child.

For Donatus imaginatio is typically deranged in cases of hypochondriacal melancholy. He gives accounts of individuals who believe in harbouring frogs in their bellies, who do not dare to walk in the belief that their feet are made of glass, who believe themselves to be wolves or demons or to have contact with demons. He discusses the question of the extent to which imaginatio can influence external objects, reserving his own judgement on this issue. He denies 
that imaginatio can produce rain, hail, storms or diseases among enemies, and asserts that it is absurd to attribute unlimited forces to imagination unless a degree of proximity exists. In dealing with the relations between imagination and the phenomena usually ascribed to sorcery or demons, he is cautious and critical, disclaiming belief in the existence of wounds which bleed in presence of the murderer.

'Imagination', therefore, was not always seen as 'imaginary' but rather as a real force, which was active at a certain distance. It was regarded as a respectable philosophico-scientific principle, related to certain notions in the field of phantasy, ideas, creativity and memory (cf. Eisler, 192730 ; Juhasz, 1971). It was a physiological principle of considerable importance and was employed to explain many varied and, from a contemporary standpoint, very heterogenous phenomena. It resembled the coeval and widespread concepts of sympathy and antipathy as well as the notions of contagion or poison which are still in use, though they have undergone a considerable transformation of meaning. Medicine has, of course, always been embedded in the general world view of its period, as may also be seen in the book, On the Forces of Imagination, by the Louvain medical professor Thomas Fienus (1567-1631), published in 1635. Fienus discusses the medical effects of imagination (in terms of physiology, pathology and therapy) in connection with a general theory of mind-body relations and the relationship of man to his visible and and invisible environment.

The doctrine of imagination is a central element in the medical doctrine of John Baptista van Helmont (1577-1644) (1683). Van Helmont had studied philosophy and several sciences before turning to medicine. Today he is best known as the discoverer of carbon dioxide and the notion of gases, but he also cultivated the chemical approach in medicine. Influenced by Paracelsus (1493-1541) and by Plato's (429-348 B.C.) doctrine of ideas, van Helmont developed his doctrine of the 'archeus influus' as a major physiological principle in the human organism. He outlined the archei of the organs, locating the supreme archeus in the stomach and the spleen. The archeus, however, was simultaneously regarded as a psychological principle. In diseasestates the archeus, under the influence of an 'idea morbosa', was no longer able to exercise the normal regulation of the functions of the organism. Accordingly, van Helmont's disease was essentially 'imagined' but was not unreal. It began as something immaterial, but then became transformed into material reality. Indeed, the image of a disease can assume aetiological significance: "Thus plagues are seen which arise from stupid imagination and fright, without the presence (of sick people) in the infected places. And these become rapidly toxic.' Images can be impressed upon the stomach or, as van Helmont says, 'sealed' into it, 'impressions' being used in the narrowest sense of the word. Haemorrhages, jaundice, cardiac tremor, amenorrhoea, paresis can also be ideogenic. "Thus the spittle of a rabid dog, the bite of a tarantula, a snake, the juice of aconite or nightshade can transmit to us against our will the image of frenzy.'

Van Helmont used his notion of images to rationalize his opinion that the victim's corpse began to bleed in the presence of the murderer. He derived this phenomenon from the impression made by the image of vengeance in the blood. Such an example illustrates the way in which the theory of imagination, though immaterial in itself, was well able to lead to very tangible consequences, even to the point of bloody consequences when a murderer received capital punishment. 'In the beginning imagined things are nothing but phantastic poems. But they do not remain that way. Because phantasy is a seal like faculty, called imagination, which is able to produce pictures or forms out of the imagined things.'

As the seat of a minor archeus, every organ was seen as capable of being the locus of imagination. Thus, blood, the heart, the oesophagus or the uterus could become the seat of pathogenic imagination. Yet the principal site always remained, at least in the male, the spleen, on account of its relationship to the supreme archeus. The central location of the spleen in the trunk of the body 'between stomach, heart and uterus' was viewed as the root of the whole body. Disease began through 'an indomitable imagination, which cannot be submitted to volition, and is located in the spleen'. The spleen is a centre, according to van Helmont, 'a fountain of the pictures produced by the imagination of man as well as of the pictures produced by the vital spirits'. 
Dreams too originated in the spleen, as did sexual desire, especially of men (cf. Bartholin, 1677). Women had a second source, the uterus, a fact which showed that in 'a woman a double government does exist'. In the same vein it was said: 'The uterus is quasi another spleen'. And, again: 'Under these conditions woman is a miserable creature. She is submitted to many diseases as a human being. But she is submitted a second time to these diseases on account of the essence of the uterus. She is up to this day punished twice, as if Eve had sinned doubly.'

In this way, van Helmont saw diseases of imagination arising in the spleen and in the uterus respectively as, in a sense, models of disease. In the following two sections I shall trace the career of these two models during the eighteenth and nineteenth centuries.

\section{SPLEEN (UPPER ABDOMEN) AND HYPOCHONDRIA}

The idea morbosa becomes an imaginary disease

The disease of imagination, originating in the spleen, has developed directly into an imaginary disease, nosophobia. The notion of imagination has become dematerialized; the 'imagination' of our ancestors is no longer the 'imagination' of Brockhaus and Webster in 1958 and 1960. The hypochondria of van Helmont has become modern hypochondria. Van Helmont's 'hypochondria' was physically located in the hypochondrium - 'hypo' meaning below, 'chondros' meaning cartilage and hypochondrium indicating the soft part of the body situated below and behind the cartilaginous parts of the ribs: the region of the stomach, the liver and the spleen. Thus, van Helmont (1683) says of the images inhabiting the spleen: 'They have something hypochondriac'. To him they were images which 'often produce such states that show signs of hypochondriac craziness and of confusion and destruction'. For van Helmont his splenic disease of imagination was hypochondriac-but the physical sufferings of his hypochondriacs were based on somatic reality. To him imagination was not imaginary.

During the eighteenth century the diagnosis of hypochondria reached epidemic proportions throughout the world (Fischer-Homberger, 1970). It was also called 'spleen', but the present meaning of 'spleen' as a reality-deforming condition did not emerge until later.

Here some additional remarks are necessary. Hypochondria was not only regarded as the result of pathogenic images in the spleen; it was, even more often, the result of pathogenic humours, especially 'black bile'. The doctrine of the four humours postulated that the organism was a mixture of blood, phlegm, yellow bile and black bile, with disease as the consequence of an imbalance between these humours, just as for van Helmont it was an imbalance between ideas. Even within the framework of the humoral doctrine the spleen played an important role as the locus of the formation or storage of black bile. In the context of humoralism black bile was the pathogenic humour par excellence, differing from the other three juices in always exhibiting a pathological tendency. An excess of black bile produced 'melancholy' (melas = black, chole $=$ bile). Originally black bile was seen as responsible for depression, and also for gastro-intestinal diseases, cancer and malaria. In malaria the spleen, swollen from an abundance of black bile, was palpable and the skin showed a yellowish-blackish tint.

The 'hypochondria' of the eighteenth century replaced in a certain sense the classical 'melancholia'. Eighteenth-century opinion was no longer firmly convinced of the correctness of the doctrine of the four humours, and doubts concerning the existence of black bile had arisen. Medical thought had become more anatomical and more localistic. Thus, there are references to the spleen and the hypochondriac region rather than to black bile, to hypochondria rather than to melancholy. The old black humour, though, still haunted the scene as the blackish 'vapour' (Fischer-Homberger, 1972). These vapours of the upper abdomen produced the common flatulence of eighteenth-century hypochondriacs which they observed so diligently and so intensely. Hypochondria acquired many pen-names like 'windige Melancholey', 'Blähsucht' or 'Windsucht' in Germany, 'vapeurs' in France, and 'vapours' in England. Like melancholy, or the troubles of van Helmont's spleen archeus, hypochondria had many symptoms. Like its predecessors it was originally regarded as a rather dangerous disease, expressing itself as tetanus, black vomit and jaundice (Whytt, 1766). Some authors thought it to be the 
cause of the depopulation of the globe, a fearful danger regarded as serious during the eighteenth century (Bilguer, 1767). Disturbances of the psyche were also among its most typical symptoms, especially when the hypochondriac gases and noxious agents ascended to the head (Bartholin, 1677). During the eighteenth century the old tradition of locating the soul, at least partly, in the upper abdomen (so closely related to the doctrine of melancholy and of van Helmont) fell into oblivion and the central nervous system, in particular the brain, became the single seat of the soul. Forms of imagination, fixed ideas, 'spleens' or whims were all products of cerebral affections. Even today we speak of something 'going to someone's head' or of a 'swollen head' when referring to conceit.

Forms of imagination were among the most important mental symptoms of hypochondria. 'Imagination diseases' occupied a central position, reverting to van Helmont's association of spleen, disease, hypochondria and imagination. Only during the eighteenth century did the concept of hypochondriac imagination lose credibility compared with its status at the time of van Helmont. Imagination became no longer the true cause of actual bodily changes; rather, it was at best a nonspecific symptom of a bodily disease of decreasing importance. In the course of the eighteenth century hypochondria thus became the 'imaginary disease' of modern times. Carl von Linné (1707-78), physician and taxonomist, who classified not only plants and animals but also diseases, put hypochondria into his class 5 - 'mental diseases', subcategory 'imaginary diseases' - and defined it as 'imaginatio fati lethalis ex levi malo' (from Cullen, 1786). Another systematist of the period, William Cullen (1710-90), called hypochondria a disease "in which a patient on the basis of mild indispositions believes himself to be in mortal danger' (Cullen, 1786). At the end of the century hypochondriasis was called 'the imagination of a certain condition of the body, which actually is not affected' (J. B. Erhard, in Fischer-Homberger, 1970).

Nevertheless, if hypochondria had not retained a certain degree of credibility it would not have occasioned concern among physicians. It continued to be regarded as either a symptom, a real bodily disease or a psychological reality. In 1766 John Hill (1716-75) wrote that to call the hypochondriac disease imaginary represented ignorance or cruelty; he argued that it was a real and tragic disease, an obstruction of the spleen caused by thickened, abnormal blood, often extending into the liver and other parts (Hill, 1767).

In 1767 Ulrich Bilguer (1720-96) derived hypochondriac insanity from 'bilious matter deposited in the abdomen' and 'deranging the workshop of thinking'. John Gregory (1724-73) wrote that the fears of the hypochondriacs - which he now related to nervous disorder - were in general without foundations, but their sufferings were real. To treat their complaints with irony or contempt as the effects of a deranged imagination, was deemed by him to be as cruel as it was stupid. The complaints were seen as arising mostly from bodily noxae and, even if the situation were different, it always remained the duty of the doctor to succour the sick. Disturbances of imagination were as much a task for the doctor as the somatic derangements (Gregory, 1778).

Immanuel Kant (1724-1804) differentiated 'hypochondria vera' from 'hypochondria abdominalis'. The former, he believed, had no locus in the body and was a product of imagination, so that it could be termed 'poetica'; the latter, by contrast, had an organic basis. 'Hypochondria vera' should, he maintained, be taken as seriously as 'hypochondria abdominalis', being a mental disease which cannot be cured by reasonable discussion. 'A reasonable person does not produce this form of hypochondriasis' (Kant, 1859).

This psychological reality was conceded during the nineteenth and twentieth centuries. This explained why physicians did not exclude the sufferer from imaginary disease from their care and reserved for him the diagnostic label 'hypochondria'. The 'Arbeitsgemeinschaft für Methodik und Dokumentation in der Psychiatrie' (1971) has defined it as: 'an abnormal, anxious relationship towards one's own body: an objectively unfounded fear, to be or become sick'. It is the paradigm of a feeling of sickness, to which no bodily reality corresponds.

\section{UTERUS AND HYSTERIA}

\section{Imagination remains dominant}

The imagination-diseases of the uterus - hysteria (hystera $=$ uterus) in its widest sense-de- 
veloped in another direction. Van Helmont called the uterus 'another spleen', and it is legitimate to ask whether the uterus as the seat of imagination was not the model for the doctrine of imagination-diseases. In one sense the uterus is the prototype of an organ of imagination. In the Aristotelian tradition it was seen as physiologically predestined to receive imagination, the image of man.

According to Aristotelian teaching, procreation is the transfer of the image of the man to the female; that is, the effect of the material formative principle of the male seed upon menstrual blood, the matter out of which the offspring is formed. Thus, procreation produces males, duplicates of the father. Everything else is the result of inhibition or degeneration of the creative male impulse (Aristotle 1963: IV, III, p. 767, 11. 14-23).

Procreation thus becomes a form of imagination. Consequently, it became possible to assume another 'false', purely maternal, type of procreation or imagination. The occurrence of hydatidiform males could thus be explained by 'lascivious imagination without intercourse' (Plenk, 1782; cf. Bohn, 1686).

If inadequate images enter the uterus, they lead to diseases of hysterical imagination in a more limited sense. The uterus becomes the seat of pathogenic images which, according to van Helmont, are not 'the splenetic, cursed images of witches which harm others... These females do damage only to themselves; they bewitch, deceive, weaken only themselves and impress upon themselves such images that drive them and drag them towards things they would otherwise never demand. And they cannot complain enough about the nonsensical drives which they generate against their own will'. Van Helmont, speaking of the diseases of the uterus, states that hysteria originates 'in certain emotions, and images arising from them; often the whole person is destroyed, as if one destroys a wasp's nest'.

Thus, these imagination-diseases are basically pathological impregnations and products. Hysterical pregnancy is only one special case. 'Uterine diseases do not arise from spoiled semen, but they are the fruits which follow the images.'

The frequent resemblance between child and mother was explicable through imagination and, even more so than with Aristotle, without the assumption of female semen. The marked resemblance of mother and child was seen as the result of frequent maternal sessions in front of a mirror during pregnancy.

When children resembled a neighbour or friends more than the father, this was no proof of maternal infidelity. This implication of the doctrine of imagination was always of great interest in legal medicine. The courts tended to preserve the interests of the accused as well as of the State towards the legitimization of children and the preservation of families. In this respect the theory of imaginatio was a useful instrument.

Giovanni Battista Codronchi (1547-1628), one of the earliest, perhaps the first, of the authors concentrating on legal medicine, devotes a long chapter to the question of whether the dissimilarity between a newborn child and his father proved the adultery of the mother (Codronchi, 1597). He discusses the various older theories of similarity and the doctrine of imagination which was unknown to the earlier authors. He succeeds even here in finding classical authorities: thus, he interprets a passage in Aristotle's Problemata (1963, X, p. 10) in this way and quotes St Hieronymus' report that Hippocrates cleared a woman from the accusation of adultery on discovering a portrait in her bedroom which was responsible for the dissimilarity of the child to its father (see Céard, note 64, in Paré, 1971). In the early medico-legal treatise of the famous French surgeon, Ambroise Paré (1510-90), the child of Hieronymus is the black child of a white mother who was constantly contemplating the image of an Ethiopian (Paré, 1635). Codronchi also discusses the biblical passage, where Jacob produced mottled sheep and goats by putting partly peeled twigs into the place where the animals mated (Genesis, 30: 37-42). He concludes: the respective powers of thought and imagination are obvious; therefore the mothers of children who do not resemble their fathers can be freed from slanders.

During the seventeenth and the early eighteenth centuries imagination served as an explanatory principle for strange deliveries more than for any other phenomena. While practical considerations might have been decisive, it should not be forgotton that the doctrine of imagination is partly rooted in the uterus.

In the works of Thomas Fienus and of $\mathrm{M}$. Donatus the effects of imagination on the foetus 
play a dominant role as the paradigm of its effect on foreign bodies. Imagination produces abortions, spots and deformities. Fright and desire function as transmitters. Women who are scared by wolves during pregnancy have wolf-like babies. Encounters with monkeys, frogs and cats produce corresponding monsters (Fienus, 1635). The terms guele-de-loup and harelip are probably historical products of the theory of imagination (Fidelis, 1674, p. 492).

In the field of similarities and malformations the doctrine of imagination not only survived into the eighteenth century, but progressed (King, 1978). This development was due to the 'animism' of Georg Ernst Stahl (1660-1734) and to the 'vitalism' of the eighteenth century, which was partly derived from Stahl (1961). These doctrines based life, health and disease on a soul-like principle, the anima, or on the nervous or vital force, localized in the nervous system. Animism as well as vitalism produced extensive psychosomatic theorizing during the eighteenth century. The great German poet, Schiller, who had studied medicine, wrote under the influence of Stahl: 'The mind constructs the body for itself' (Es ist der Geist, der sich den Körper baut; Wallensteins Tod).

These theoretical tendencies strongly influenced the doctrine of maternal imagination. The early eighteenth-century authors of books on legal medicine make imaginatio the central issue in questions of similarity and dissimilarity, which are still important in legitimacy trials. Michael Alberti (1682-1757), who warns doctors and judges not be to misled by crooked women and corrupt lawyers (Alberti, 1725), possibly had in mind the 1637 decision of the Parliament of Grenoble which ruled that a woman could be impregnated via imagination when dreaming of her husband, who had been absent for four years. 'Ast crederem poticus parlamenti praesidem, vel alium bonum virum rem habuisse cum hac muliere' ('Here the president of the parliament or another man seems to have been instrumental'), wrote Paulus Ammann (1634-91), the Leipzig critic of medico-legal decisions (Ammann, 1670).

The other famous medico-legal specialist of the first half of the eighteenth century, Friedrich Teichmeyer (1685-1746), defended imagination with particular enthusiasm: posthumous children, he claimed, resemble the progenitor more than other children because the mother constantly bears the image of the deceased in mind (Teichmeyer, 1723).

Imaginatio also retained some importance in infanticide. Here again it becomes evident how lofty theories can produce very drastic sequelae. We have encountered in Donatus the possibility of infanticide 'per imaginationem'. The Swiss surgeon, Fabricius Hildanus (1560-1634), published cases of children whose appearance at birth suggested that they had been butchered or shot because their mothers had assisted in slaughtering animals or had been scared by guns (Fabriz, Cent. 3, Obs. 55; Cent. 6, Obs. 65, 1780-1783). Daniel Turner (1667-ca. 1740) attributed to imagination the power 'of producing such large and bleeding wounds on the body of the newborn as the mother had imagined' (Turner, 1766). As late as 1779 Wilhelm Gottfried Ploucquet (1744-1814) wrote of imaginatio as an alternative to infanticide (Ploucquet, 1979 a), still attributing to imagination such strong bodily effects on connection with the uterus.

Even so, in the course of the eighteenth century the scientific criticism of the doctrine of imagination eventually included the uterus. A publication of Auguste Blondel (1665-1734) is a landmark in this respect (Blondel, 1756). Blondel compared the belief in imagination with the belief in ordeals. He was fully aware of the practical importance of the doctrine of imagination, and saw two reasons for its longevity: " 1 . The philosophers have not deemed it necessary to find the natural causes of these spots and deformations. 2. The ancients regarded divine vengeance as a reason for monsters. This impressed the mind of the parents so terribly that out of love for one's next-of-skin imagination was preferred as the causal factor.' About fifty years later another author attributed these adverse effects no longer to imagination but to natural causes (cf. Rickmann, 1770).

The wounds of the newborn, says Blondel, are due to accidents and to poor obstetricians rather than to maternal phantasies. It is surprising that Blondel does not mention illegitimacy and infanticide, possibly because of his philanthropic, enlightened attitude. Blondel's arguments against imagination are mostly taken from anatomy, physiology and embryology. There are no nervous pathways from mother to child, he 
points out, and the child is predetermined in the semen. There are more plausible explanations for birthmarks than maternal imagination, including faulty disposition, intra-uterine diseases, inheritance and retarded development. Hydrocephalus, for example, is the consequence of a brain remaining in the vesicular stage. Red spots appear where the skin is still thin. Harelip, as William Harvey stated, is a consequence of inhibited development and not of an encounter with a hare (Harvey, 1847).

During the middle of the eighteenth century the Petersburg Academy once more made the theory of imagination the object of a competition for a prize. The prize went to an adherent of the doctrine of imagination, yet fame and acclaim went to Johann Georg Roederer's (1726-63) antithesis (Roederer, 1763). Roederer was a famous Göttingen obstetrician who was interested in legal medicine and had made some contributions to legal obstetrics. Albrecht von Haller (1708-77), the son-in-law of Teichmeyer, mentioned above as a specialist in legal medicine, was instrumental in bringing Roederer to Göttingen, and Roederer later took over his course in legal medicine. While Haller's course was largely a commentary on his father-in-law's text, he differed totally from the latter on the question of imagination. His criticism was based mainly on his own research on malformations (Haller, 1782-4; cf. Lundsgaard-Hansenvon Fischer, 1959). Johann Ernst Hebenstreit (1703-57), author of the leading medico-legal text of the second half of the century (Hebenstreit, 1753), was also opposed to the doctrine of imagination: the only illustration in his book is of four monsters 'ex museo autoris', one showing the skull of an infant born with a harelip. In 1775 there appeared the famous treatise on human races by Johann Friedrich Blumenbach (1752-1840). After that time the theory of imagination was only regarded as 'a poor excuse' for women whose children showed the vestiges of adultery with Asiatics, Africans, etc. (Haller, 1782-4).

In Wilhelm Gottfried Ploucquet's survey of the medical aspects of the capacity to inherit and of legitimacy (Ploucquet, 1779 b), hardly anything is left of imagination: racial differences between father and children are more readily explained by the adultery of the mother, and 'the supposedly necessary similarity to the father or mother decides nothing, as a newborn child does not have a definite physiognomy and opinion or imagination are able to create or undo similarity or dissimilarity'. The change in meaning of the concept of 'imagination' is remarkable. It would have been equally possible to maintain a hundred years earlier that "imagination creates similarity or dissimilarity', yet it would have meant something totally different. The same change is also evident in an addition to the chapter on 'monsters' in von Haller's lectures (1782): 'In older times the formation of such creatures was attributed to imagination. Today this force is only used to explain the formation of monsters in the realm of scientific thought.' Thus, imagination here has progressively lost its character of reality. The development and the deformities of children may be said to have been excluded from the group of hysterical phenomena in the wider sense of the term.

The doctrine of imagination did, nevertheless, survive in the field of hysteria. During the eighteenth century, a period of liberalism and demand for the equal rights of women, it looked as if hysteria would lose its association with the female sex and the uterus and become a nervous disease identical with hypochondria. The hysterical imagination would thereby have lost its somatic reality. However, during the nineteenth century hysteria and hypochondria again became two different concepts. Hysteria was once more regarded as a specifically female complaint, either depending on the uterus or on the ovary, which came increasingly to replace the uterus as the centre of the female organism, or as a result of the specific fragility and weakness of the female nervous system. In this way imagination regained its old aetiological function.

This trend was possibly a consequence of the fact that traditionally the uterus had been a favoured locus for reality, impinging on imagination to enter and exercise its influence. We may, furthermore, observe that historically old ideas often retain credibility longer in the field of the psyche than in somatic medicine, where their survival is most frequent in gynaecology. Thus, towards the end of the nineteenth century theories of hysteria became the refuge of the old doctrine of disease-producing ideas and pictures, preferably with sexual connotations. Hysteria, in fact, became the paradigm of psychogenic disease. 
Jean Martin Charcot (1825-93) created a psychogenic theory of hysteria, especially of the traumatic-hysterical pareses (Charcot, 1887-1888; cf. also Fischer-Homberger, 1975), and for Joseph Babinski (1857-1932) and Pierre Janet (1859-1947), both members of Charcot's school at the Salpêtrière, hysteria became the paradigm of a psychic, psychogenic affection with bodily symptoms (cf. Ellenberger, 1970).

In Vienna Moriz Benedikt (1835-1920) employed the notion of a 'second life' ('SeelenBinnenleben'), a secret region, the 'workshop of imagination' (Benedikt, 1894). This internal life of the soul was seen to be, in general, far more richly developed in women who, in the struggle for survival, had been compelled to hide their internal life more completely than men; these unrelieved internal tensions unleashed the female disease, hysteria. The material hidden by women at that period was, however, contained in their sexual phantasy-life. Sigmund Freud (1856-1939) of Vienna was originally inspired by Charcot. He attended Charcot's famous Tuesday lectures, translated them, and adopted and generalized his psychological interpretation of traumatic hysteria. On the other hand, like Benedikt, Freud and Joseph Breuer (1842-1925) assigned to sexual ideas, e.g. the sexual trauma, a particularly important position in psychogenesis, primarily in the framework of a general theory of hysteria. In their first 'Preliminary communication on the psychological mechanism of hysterical phenomena' Breuer \& Freud (1893) refer to Benedikt's ideas. Later, Freud alone presented this point of view as part of a general theory of neuroses.

\section{IMAGINATION, IDEAS, CREATIVITY}

\section{The psychogenesis of phenomena in the twentieth century}

During and after the World Wars, especially in the course of the past twenty years, the "imaginatio' concept has again gained ground. Having been virtually confined to the pathology of the uterus, or at least to the supposedly weak female nervous system, during the nineteenth century, it now expanded beyond these limits far into normal everyday life. The idea that images may form and change reality, even material reality, which had been considered irrational and belonging to magic for a long time, has again become part of a current stream of rationalization. The concept of ideas or ideals - images in the widest sense - shaping human expectations, experience and environment has become increasingly familiar. 'Phantasy' and 'creativity' have been markedly revalued in the past decade. The behavioural sciences have introduced the notions of 'imprinting' and the 'Suchbild' (searching image) (Uexküll \& Kriszat, 1934). Jungian psychology has introduced the notion of 'archetypes'. Psychoanalysis has popularized the nineteenth-century concept of hysteria and thus of the classical disease of imagination as a general concept of neurosis. In psychosomatic medicine it is a basic assumption that psychological factors, and therefore all kinds of images in the old sense of the word, can profoundly affect bodily function.

It seems that the two World Wars have substantially accelerated the spread of all these concepts by demonstrating so plainly the possibilities of the anti-human use of natural sciences and technology which had not hitherto been appreciated. In this way they profoundly shook the nineteenth-century belief that technical and scientific progress quasi-automatically liberate humanity from evil and disease and that scientific findings reflect undistorted reality or truth itself. Thus, what could be called the nineteenthcentury claim of the exact sciences to a monopoly of scientific respectability was broken, and other sciences were given a new chance to emerge after the wars. Psychoanalysis, indeed, had its first spectacular boom after the first World War, psychosomatics and other psychological concepts even more after the second.

The enormous technical and scientific progress of somatic medicine, especially in the field of therapeutics in the 1940s, 1950s and early 1960 s, has prevented a broader diffusion of psychological thought into general medicine. After having been desired for centuries such progress was accepted as unquestionably beneficial and it seemed that neither patients nor doctors needed conceptual alternatives to traditional somatic medicine. Only in the course of the late 1960s and the early 1970s have the psychological aspects of patients and their illnesses - hitherto regarded as a matter for specialists and more or less restricted to psychiatry - been markedly diffused to medicine in general. During these years the problems of side-effects of drugs, the process of uncritical 
mechanization and sometimes irrational rationalization, and the ethical, social, economic, and psychological issues associated with medicine have received increasing attention. In the course of this period it has become almost fashionable to question and to criticize the technical and somatic approach to human disease and to cultivate psychological approaches: medical psychology became a little less marginal and a little more of a basic medical science. Accordingly, the ground was prepared for the 'renaissance' of the imagination-concept and for a general revival of the idea of the conversion of psychologically defined mental images into phenomena comprehensible by natural science. The most pronounced difference between the old and the modern ideas is that the earlier doctrine was regarded as an objective science, whereas the modern concepts imply subjective and personal dimensions of the imaginative processes as well as of their investigation. It is relevant to observe that the 1968 edition of Brockhaus' encyclopaedia no longer includes the term 'Einbildung' (imagination), perhaps because the definition, 'mental images to which no corresponding reality exists', is no longer acceptable. On the other hand, there is a reference to 'Einbildungskraft' ('force of imagination'). While the inclusion of this term, which is close to phantasy and creativity, could be coincidental, it could also represent part of the changing notions of 'reality' which have emerged during the 1960s.

\section{CONCLUSION}

In conclusion, it is apparent from this medicohistorical survey that the concept of reality changes to reflect the climate of opinion, possibly because it is closely related to those powers and authorities recognized at different epochs. Since there is a strong tendency to submit to those powers and authorities which seem to be useful and of which one seems to be a part, nineteenth-century man endowed the results and developments of technology and natural science with a strong sense of reality, largely because they provided him with so much that was agreeable and useful. Imagination then became a largely feminine province. On the other hand, twentieth-century man, who often feels threatened and helpless in the face of these conse- quences, prefers to find reality in his own experience and to look at science and technology as forms of science-fiction. The engineer who continues to perceive his machines as a world of reality now differs little from the sectarian who is convinced of the reality of his conversion experience. The politician usually calls the insecure foundations of his opinions 'hard facts'. Somatic physicians regard somatic diseases as the only genuine disorders. Psychotherapists fight for the reality of psychological disturbances. It has again become necessary to re-assess the nature of reality in medicine, as well as in other fields of knowledge.

This work was made possible by the generous help of the Swiss National Science Foundation.

\section{REFERENCES}

Alberti, M. (1725). Systema jurisprudentiae medicae. Orphanotropheum: Halle.

Ammann. P. (1670). Medicina critica; sive decisoria, centuria casuum medicinalium in Concilio Facult. Med. Lips. antehac resolutorum. Hertz, Ohler: Erfurt.

Arbeitsgemeinschaft für Methodik und Dokumentation in der Psychiatrie (1971). Das AMP-System. Springer: Berlin.

Aristotle (1963). Generation of Animals. Harvard University Press: Cambridge, Mass.

Bartholin, T. (1677). Neu-verbesserte künstliche Zerlegung des menschlichen Leibes. Hoffmann: Nürnberg.

Benedikt, M. (1894). Second life. Das Seelen-Binnenleben des gesunden und kranken Menschen. Wiener Klinik 20, $127-$ 138.

Bilguer, J. U. (1767). Nachrichten an das Publikum in Absicht der Hypochondrie, etc. Rothe: Copenhagen.

Blondel, J. A. (1756). Erste Abhandlung über die Einbildungskraft der schwangeren Weiber in ihre Leibesfrucht. Drey...Abhandlungen. König: Strassbourg. (English edition: 'The Strength of the Imagination of Pregnant Women Examined.... London, 1727.)

Blumenbach, J. F. (1776). De generis humani varietate nativa. Vandenhoeck: Göttingen.

Bohn J. (1686). Circulus anatomico-physiologicus, seu oeconomia corporis animalis. Gleditsch, Fleischer: Leipzig.

Breuer, J. \& Freud, S. (1893). Ueber den psychischen Mechanismus hysterischer Phänomene (vorläufige Mitteilung). Neurologisches Centralblatt 12, 4-10, 43-47.

Brockhaus, der neue (Encyclopaedia in 5 vols.) (1960). Vol. 2. Brockhaus: Wiesbaden.

Brockhaus Enzyklopädie (in 20 vols.) (1968). Vol. 5. Brockhaus: Wiesbaden.

Charcot, J. M. (1887). Leçons sur les maladies du systeme nerveux faites à la Salpétrière, Vol. 3. Progrès médical, Delahaye et Lecrosnier: Paris.

Charcot, J. M. (1887-1888). Poliklinische Vorträge (leçons du mardi), 1 (transl. S. Freud). Deuticke: Leipzig-Wien. (Vol. 1 (2nd edn). Progrès medical: Paris, 1892.)

Codronchi, B. (1597). Methodus testificandi. In: De vitiis vocis libie duo. Wechelus, Marvius, Aubrius: Frankfurt.

Cullen, W. (1786). Kurzer Inbegriff der medizinischen Nosologie. Fritsch: Leipzig. (First edition: Synopsis nosologiae methodicae. Edinburgh, 1769.) 
Donatus, M. (1588). De medica historia mirabili. Valgrisius: Venice. (First edition: Mantua, 1586.)

Eisler, R. (1927-30). Wörterbuch der philosophischen Begriffe. Mittler: Berlin.

Ellenberger, H. F. (1970). The Discovery of the Unconscious. Basic Books: New York.

Fabriz, W. (1780-3). Chirurgische Beobachtungen und Curen. Korten: Flensburg, Leipzig.

Fidelis, F. (1674). De relationibus medicorum libri quatuor. Tarnovius. Leipzig. (First edition: Palermo, 1602.)

Fienus, T. (1635). De viribus imaginationis tractatus. Elsevir: Leyden.

Fischer-Homberger, E. (1970). Hypochondrie. Melancholie bis Neurose... Huber: Bern-Stuttgart-Wien.

Fischer-Homberger, E. (1972). Hypochondriasis of the eighteenth century - neurosis of the present century. Bulletin of the History of Medicine 46, 391-401.

Fischer-Homberger, E. (1975). Die traumatische Neurose. Vom somatischen zum sozialen Leiden. Huber: BernStuttgart-Wien.

Gregory, J. (1778). Vorlesungen über Pfichten and Eigenschaften eines Arztes. Fritsch: Leipzig. (English edition: London, 1770.)

Haller, A. I. (1782, 1784). Vorlesungen über die gerichtliche Arzneiwissenschaft. Neue typographische Gesellschaft: Bern. (After notes of lectures in 1750/51.)

Harvey, W. (1847). Anatomical exercises on the generation of animals. In The Works. Sydenham Society: London. (First Latin edition: London, 1651.)

Hebenstreit, J. E. (1753). Anthropologia forensis sistens medici circa rempublicam causasque dicendas officium. Haeredes Lankisianorum: Leipzig.

Helmont, J. B. van (1683). Aufgang der Arztney-Kunst (German transl. F. M. van Helmont.) Endters Söhne: Sulzbach.

Hill, J. (1767). Practische Abhandlung über die Natur und Cur der Krankheit, welche man die Milzkrankheit oder die Hypochondrie nennet. Förster: Bremen. (English original: London, 1766.)

Juhasz, J. B. (1971). Greek theories of imagination. Journal of the History of the Behavioral Sciences 7, 39-58.
Kant, I. (1859). Von der Macht des Gemüths, durch den blossen Vorsatz seiner krankhaften Gefühle Meister zu sein (11th edn.) Geibel: Leipzig.

King, L. S. (1978). The Philosophy of Medicine. Harvard University Press: Cambridge, Mass.

Lundsgaard-Hansen-von Fischer, S. (1959). Verzeichnis der gedruckten Schriften Albrecht von Hallers. Huber: Bern.

Paré, A. (1635). Arzneispiegel. Rötell, Fischers Erben: Frankfurt.

Paré, A. (1971). Des monstres et prodiges. Droz: Geneva. Plenk, J. J. (1782). Anfangsgründe der gerichtlichen Artzneywissenschaft und Wundartzneykunst. Gräffer: Vienna.

Ploucquet, W. G. $(1779 a)$. Abhandlung über die gewaltsamen Todesarien. Berger: Tübingen.

Ploucquet, W. G. (1779b). Ueber die physischen Erfordernisse der Erbfähigkeit der Kinder. Heerbrandt: Tübingen.

Rickmann, C. (1770). Von der Unwahrheit des Versehens und der Hervorbringung der Muttermahle durch die Einbildungskraft. Gollner: Jena.

Roederer, J. G. (1763). De vi imaginationis in foetum negata, quando gravidae mens a caussa quacunque violentiore commovetur. In Opuscula medica. Bossiegelius: Leipzig.

Stahl, G. E. (1961). Uber den mannigfaltigen Einfluss von Gemütsbewegung auf den menschlichen Körper (Halle, 1695). Barth: Leipzig.

Teichmeyer, H. F. (1723). Institutiones medicinae legalis vel forensis. Bielckius: Jena.

Turner, D. (1766). Abhandlung von den Krankheiten der Haut. Richter: Altenburg. (English edition: De morbis cutaneis. A treatise of diseases incident to the skin. London, 1714.)

Uexküll, J. J. \& Kriszat, G. (1934). Streifzäge durch die Umwelten von Tieren und Menschen. Ein Bilderbuch unsichtbarer Welten. Springer: Berlin.

Webster's New World Dictionary of the American Language (1958). New York.

Whytt, R. (1766). Beobachtungen über die Natur, Ursachen und Heilung der Krankheiten, die man gemeiniglich nerven. hypochondrische und hysterische Zufälle nennet, Fritsch: Leipzig. (After the second English edition of 1765 , Edinburgh; the first edition appeared in the same year.) 